\title{
Production Efficiency and Soil Studies of Linseed (Linum usitatissimum L.) Based Intercropping Systems as Influenced by Integrated Nutrient Management under Rainfed Condition
}

\author{
Amar Kant Verma ${ }^{1 *}$, P.N. Yadav ${ }^{1}$, U.D. Awasthi ${ }^{1}$ and Rahul Ranjan' \\ ${ }^{1}$ Department of Soil Conservation and Water Management, ${ }^{2}$ Department of Soil Science and \\ Agricultural Chemistry, C S Azad University of Agriculture and Technology, \\ Kanpur -208002 (U.P.), India \\ *Corresponding author
}

A B S T R A C T

\section{Keywords}

Physical, Physicochemical and chemical

characteristics, Linseed equivalent yield, Production efficiency

Article Info

Accepted:

07 November 2018

Available Online:

10 December 2018
A field experiment was conducted during rabi seasons of 2015-16 and 2016-17 at Soil Conservation and Water Management Farm of C S Azad University of Agriculture and Technology, Kanpur to find out suitable row ratio of linseed + lentil/barley in intercropping systems under rainfed condition. The results revealed that linseed performed better in intercropping than sole cropping. Among different cropping systems, linseed + lentil (3:1) exhibited maximum linseed equivalent yield of 13.33 $\& 12.11 \mathrm{q} \mathrm{ha}^{-1}$ and earned maximum production efficiency of $9.81 \& 9.25$ $\mathrm{Kg} \mathrm{ha}^{-1}$ day $^{-1}$ respectively, during the two years of experimentation.

\section{Introduction}

In today's agriculture diversification and intensification of crop and their combination and sequence both in space and time with new adoptable and remunerative crops and their species has become absolutely necessary as the present food base has been narrowed down coupled with effect of climate change making it prone to frequent crop failures. The high input based agriculture in present situation is showing signs of stress, and long term cereal based or nutrients exhaustive crops are putting a question mark on long term sustainability especially under dry land situations. As practiced from earlier days, intercropping is a useful proposition for increasing the productivity and income per unit area/time in agriculture besides enhancing the water and land use efficiency under rainfed conditions. Today intercropping with various nonexploited crops are gaining importance due to 
their adoptability to changing climatic conditions prevailing in the region and for achieving higher returns under adverse conditions. This necessitates development of an appropriate intercropping technology for different crops especially minor crops which are grown on a limited area. Linseed is one among minor crops which is of economic value because of its common usage in animal feed, oil extraction, etc. The area under linseed crop cannot be increased because of the inflexibility of existing cropping systems. Hence, the only way to increase the productivity of such crops is to grow them in association with other crops in such a pattern that the productivity of the base crop is least affected by the associated crop and the production per unit area is also increased.

\section{Materials and Methods}

A field experiment was conducted during rabi seasons of 2015-16 and 2016-17 at Soil Conservation and Water Management Farm of C S Azad University of Agriculture and Technology, Kanpur in alluvial soil under rainfed condition. The soil of the experimental field was sandy loam in texture and slightly calcareous. The field experiment was conducted in split plot design with three replications, keeping cropping systems in main plots and INM in subplots. The treatment comprising 9 cropping systems viz. $\mathrm{C}_{1}$ : Linseed sole, $\mathrm{C}_{2}$ : Lentil sole, $\mathrm{C}_{3}$ : Barley sole, $\mathrm{C}_{4}$ : Linseed + lentil (3:1), $\mathrm{C}_{5}$ : Linseed + barley (3:1), $\mathrm{C}_{6}$ : Linseed + lentil (4:1), $\mathrm{C}_{7}$ : Linseed + barley (4:1), $\mathrm{C}_{8}$ : Linseed + lentil $(5: 1)$ and $\mathrm{C}_{9}$ : Linseed + barley $(5: 1)$ and 3 integrated nutrient management viz. $\mathrm{N}_{1}: \mathrm{RDN}, \mathrm{N}_{2}: 75 \%$ RDN through inorganic $+25 \%$ RDN through vermicompost $\mathrm{N}_{3}: \quad 75 \% \quad \mathrm{RDN}$ through inorganic $+25 \%$ RDN through vermicompost + bio-fertilizer (seed coating) + PSB @ $2.5 \mathrm{~kg}$ $\mathrm{ha}^{-1}$ in soil. Linseed cv Padmini, lentil cv K-75 and barley cv Haritma was grown $25 \mathrm{~cm}$ apart. Crops were sown on 20.11.2015 and 26.11.2016 where as linseed was harvested on 30.03.2016 and 03.04.2017, lentil 04.04.2016 and 06.04.2017 and barley on 26.03.2016 and 01.04.2017 during the first and second year of experimentation, respectively. Available moisture at sowing time up to $100 \mathrm{~cm}$ soil profile was measured which was 281.7 and $277.5 \mathrm{~mm}$. The amount and distribution of rainfall received during cropping season was 49.9 and $32.8 \mathrm{~mm}$ in 2015-16 and 2016-17, respectively against the average annual rainfall of about $800 \mathrm{~mm}$. Recommended package of practices and fertilizers doses were applied in different treatments. Production efficiency was calculated by following given formula below (Kumawat et al., 2012)

\section{Production efficiency $\left(K g h a^{-1} d a y^{-1}\right)=$}

\section{Grain yield $\left(\mathrm{Kg} \mathrm{ha}^{-1}\right)$ / Total duration taken crop (Days)}

Linseed equivalent yield ( $\left.\mathrm{q} \quad \mathrm{ha}^{-1}\right)$ was calculated by following given formula below (Lal and Ray, 1976).

$$
\begin{aligned}
& \text { LESY (q ha }{ }^{-1} \text { ) }=\frac{\text { Seed Yield of lentil (q ha }{ }^{-1} \text { ) } \times \text { Seed price of lentil (Rs. } \mathrm{q}^{-1} \text { ) }}{\text { Seed price of linseed (Rs. } \mathrm{q}^{-1} \text { ) }}+\text { Seed Yield of linseed (q ha }{ }^{-1} \text { ) } \\
& \operatorname{LESY}\left(\mathrm{q} \text { ha }{ }^{-1}\right)=\frac{\text { Seed Yield of barley }\left(\mathrm{q} \text { ha }{ }^{-1}\right) \times \text { Seed price of barley }\left(\text { Rs. } \mathrm{q}^{-1}\right)}{\text { Seed price of linseed }\left(\text { Rs. } \mathrm{q}^{-1}\right)}+\text { Seed Yield of linseed }\left(\mathrm{q} \text { ha }{ }^{-1}\right)
\end{aligned}
$$


Table.1 Pre sowing and Post harvest soil physical, physico-chemical and chemical properties of experimental field

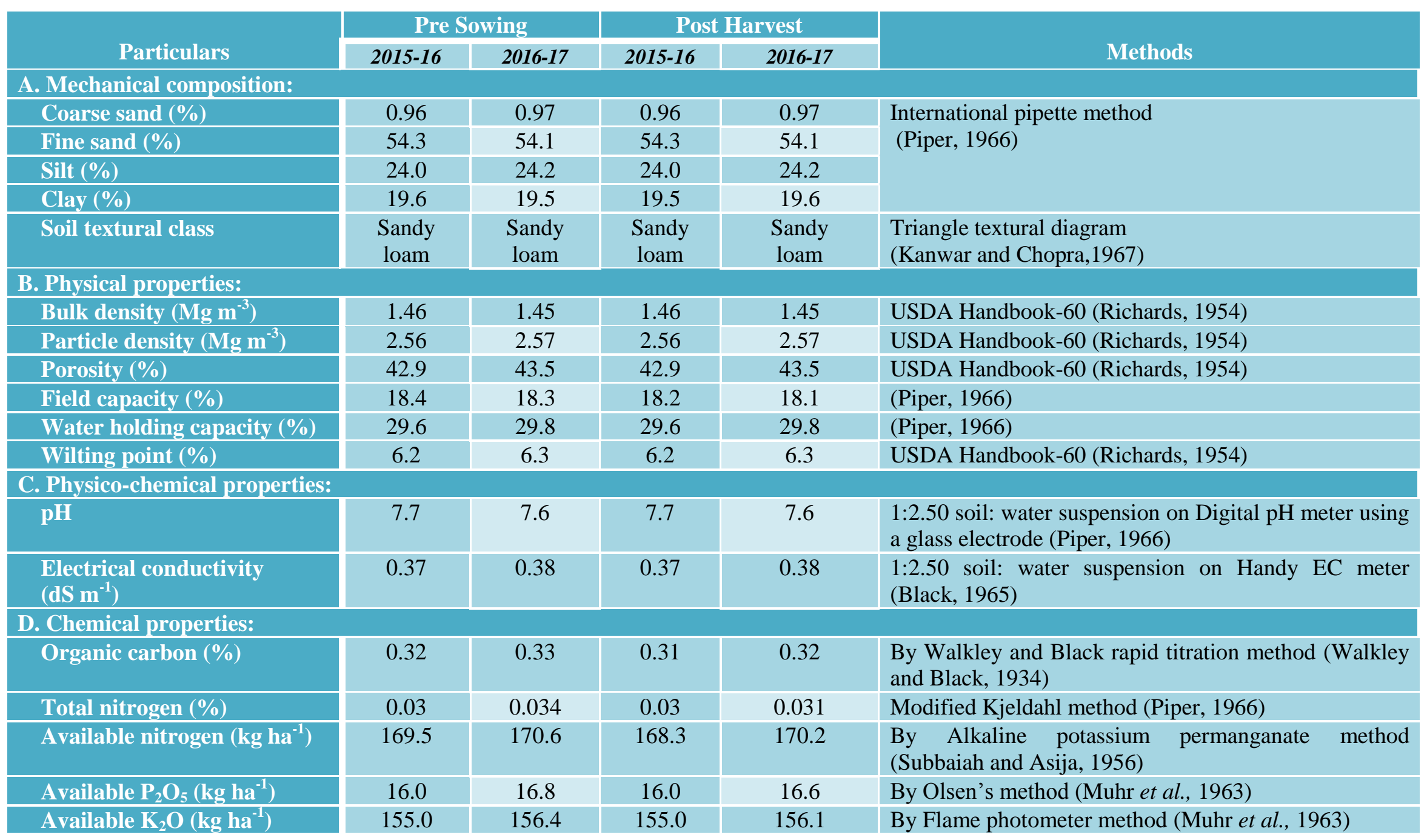


Table.2 Effect of Cropping systems and INM on Plant Stand, LEY and Production efficiency under different treatments

\begin{tabular}{|c|c|c|c|c|c|c|c|c|c|c|}
\hline \multirow{3}{*}{ Treatment } & \multicolumn{6}{|c|}{ Plant Stand $\left(000 \mathrm{ha}^{-1}\right)$} & \multirow{2}{*}{\multicolumn{2}{|c|}{$\begin{array}{c}\text { Linseed equivalent } \\
\text { yield } \\
\left(\mathbf{q} \mathrm{ha}^{-1}\right)\end{array}$}} & \multirow{2}{*}{\multicolumn{2}{|c|}{$\begin{array}{c}\text { Production } \\
\text { efficiency } \\
\left(\mathrm{Kg} \mathrm{ha}^{-1} \text { day }^{-1}\right)\end{array}$}} \\
\hline & & \multirow{2}{*}{$\begin{array}{l}\text { Lentil } \\
2015-16\end{array}$} & \multirow[t]{2}{*}{ Barley } & \multirow[t]{2}{*}{ Linseed } & \multirow{2}{*}{$\begin{array}{l}\text { Lentil } \\
2016-17\end{array}$} & \multirow[t]{2}{*}{ Barley } & & & & \\
\hline & & & & & & & 2015-16 & 2016-17 & $2015-16$ & 2016-17 \\
\hline \multicolumn{11}{|l|}{ Cropping systems: } \\
\hline $\mathrm{C}_{1}$ Linseed sole & 680.64 & - & - & 680.26 & - & - & 10.61 & 9.66 & 8.10 & 7.55 \\
\hline $\mathrm{C}_{2}$ Lentil sole & - & 568.20 & - & - & 558.62 & - & 8.93 & 7.70 & 6.57 & 5.88 \\
\hline $\mathrm{C}_{3}$ Barley sole & - & - & 120.79 & - & - & 120.45 & 6.64 & 5.84 & 5.23 & 4.64 \\
\hline $\mathrm{C}_{4}$ Linseed + lentil $(3: 1)$ & 456.71 & 190.16 & - & 444.59 & 199.41 & - & 13.33 & 12.11 & 9.81 & 9.25 \\
\hline $\mathrm{C}_{5}$ Linseed + barley $(3: 1)$ & 445.55 & - & 40.03 & 443.76 & - & 39.66 & 11.29 & 10.56 & 8.31 & 8.07 \\
\hline $\mathrm{C}_{6}$ Linseed + lentil $(4: 1)$ & 519.96 & 141.03 & - & 456.03 & 145.43 & - & 12.30 & 11.58 & 9.05 & 8.84 \\
\hline $\mathrm{C}_{7}$ Linseed + barley $(4: 1)$ & 517.47 & - & 29.65 & 452.40 & - & 28.63 & 10.76 & 10.18 & 7.92 & 7.78 \\
\hline $\mathrm{C}_{8}$ Linseed + lentil (5:1) & 544.21 & 113.71 & - & 519.96 & 108.93 & - & 11.94 & 10.94 & 8.78 & 8.36 \\
\hline $\mathrm{C}_{9}$ Linseed + barley $(5: 1)$ & 543.56 & - & 24.39 & 516.07 & - & 24.23 & 10.00 & 9.31 & 7.36 & 7.11 \\
\hline SE (d) & 1.17 & 0.52 & 0.78 & 0.93 & 0.51 & 0.62 & 0.28 & 0.37 & - & - \\
\hline $\mathrm{CD}(\mathrm{P}=0.05)$ & 2.59 & 1.31 & 1.95 & 2.05 & 1.24 & 1.55 & 0.59 & 0.78 & - & - \\
\hline \multicolumn{11}{|c|}{ Integrated nutrient management: } \\
\hline $\mathbf{N}_{1}$ & 528.75 & 252.63 & 53.19 & 500.53 & 252.03 & 53.40 & 9.75 & 8.90 & 7.47 & 7.06 \\
\hline $\mathbf{N}_{2}$ & 529.80 & 253.57 & 53.60 & 501.43 & 252.98 & 53.19 & 10.62 & 9.73 & 8.97 & 7.14 \\
\hline $\mathbf{N}_{\mathbf{3}}$ & 530.63 & 253.64 & 54.36 & 503.60 & 254.16 & 54.14 & 11.59 & 10.69 & 9.78 & 8.98 \\
\hline SE (d) & 0.64 & 0.87 & 0.35 & 0.60 & 0.65 & 0.38 & 0.16 & 0.19 & - & - \\
\hline $\mathrm{CD}(\mathrm{P}=0.05)$ & 1.32 & NS & 0.75 & 1.23 & NS & 0.81 & 0.32 & 0.39 & - & - \\
\hline
\end{tabular}




\section{Results and Discussion}

The soil of the experimental field was subjected to laboratory analysis for physical, physico-chemical and chemical characteristics and given in (Table-1). The data on soil characteristics did not show conspicuous variation however, considering the situation of the present experiment, the application of inorganics in conjugation with organics in rainfed condition not only increased yield and economic return but also depicted a positive balance of available nitrogen, phosphorus and potassium which can be judiciously used by the succeeding crop and helps in maintaining soil health. This study further strengthens the role of organic sources of nutrients in maintaining soil health. Whereas, their combination with inorganic sources in appropriate ratios helps to maintain higher yields. Additionally organic sources also improve yields through increased moisture retention in these moisture deficient alluvial soil. Similar views was also expressed by (Kumawat et al., 2018).

The maximum final plant stand were recorded in linseed sole while the marked reduction in final plant stand (Table-2) were observed in intercropping systems. It may be due to reason that intercropping was tested in replacement series where replacement by intercrop might have reduced linseed population. Further, different doses of INM application showed significantly highest values with the application of $75 \% \mathrm{RDN}$ through inorganic $+25 \%$ RDN through vermicompost + biofertilizer (Seed coating) + PSB @ $2.5 \mathrm{Kg} \mathrm{ha}^{-1}$ incorporated in the soil as compared to lowest under RDN during both the years of observation. Similar views have also been expressed by (Singh et al., 2017).

The linseed equivalent yield (Table- 2) was significantly highest under linseed + lentil (3:1) followed by linseed + lentil (4:1) whereas lowest equivalent yield was obtained in the treatment of linseed + barley $(5: 1)$ among different cropping systems during two different years. Application of $75 \%$ RDN through inorganic $+25 \%$ RDN through vermicompost + biofertilizer (seed coating) + PSB@2.5 kg ha ${ }^{-1}$ in soil brought about significantly highest seed yield and lowest values under RDN as well as linseed equivalent yield might be due to integrated application of fertilizers and organic sources has been also reported by (Verma et al., 2017, Verma and Yadav, 2017 and Verma and Yadav, 2018).

The scrutiny of the data clearly indicate that production efficiency was maximum $(9.81 \&$ $9.25 \mathrm{Kg} \mathrm{ha}^{-1}$ day $\left.^{-1}\right)$ in the treatment of linseed + lentil (3:1) and minimum $(7.36 \& 7.11 \mathrm{Kg}$ $\mathrm{ha}^{-1}$ day $\left.^{-1}\right)$ under linseed + barley (5:1) during the two different years. Similar views have also been expressed by (Kumawat et al., 2012 and Shekhawat et al., 2015).

In conclusion, based on two years of experiment it may be inferred that linseed + lentil (3:1) supplemented with $75 \%$ RDN through inorganic $+25 \%$ RDN through vermicompost + biofertilizer (seed coating) + PSB @ $2.5 \mathrm{~kg} \mathrm{ha}^{-1}$ in soil has been found most suitable with respect to plant stand and LEY and production efficiency may be recommended invariably to practice under rainfed alluvial tract of Uttar Pradesh.

\section{Acknowledgement}

The first author would like to express gratitude to Department of Science and Technology, Government of India, New Delhi for providing fellowship as an opportunity to commence his Ph.D. programme in Soil Conservation and Water Management, C S Azad University of Agriculture and Technology, Kanpur. 


\section{References}

Black, C.A. 1965. Methods of Soil Analysis, part II. American Society of Agronomy, Madison, Wisconsin.

Kanwar, J.S. and Chopra, S.L. 1967. Soil Textural Diagram. Practical Agricultural Chemistry, S. Chand and Co., New Delhi, pp. 51.

Kumawat, Amit, Yadav, R.S. and Pareek, N.K. 2018. Residual effect of FYM and fertilizers on soil fertility, productivity and economics of Pearls Millet (Pennisetum glaucum L.). Journal of Soil and Water Conservation, 17 (1): 102-106.

Kumawat, N., Singh, R.P., Kumar, R., Kumari, A. and Kumar, P. 2012. Response of intercropping and integrated nutrition on production potential and profitability on rainfed pigeonpea. Journal of Agricultural Science, 4 (7): 154-162.

Lal, R.B. and Ray, S. 1976. Economics of different cropping intensities. Indian Journal of Agricultural Sciences, 46: 93-96.

Muhr, G.R., Datta, N.P., Sankarasubramoney, H., Diver, R.F., Leley, V.K. and Donadhue, R.L. 1963. Soil Testing in India U.S. Agency for International Development Mission to India, New Delhi, pp. 229-311.

Piper, C.S. 1966. Soil and plant analysis. Hans Publishers, Bombay.

Richards, L.A. 1954. Diagnosis and Improvement of Saline and Alkali Soils. USDA Handbook-60, Oxford and I.B.H. Publishing House, New Delhi.
Shekhawat, P.S., Kumawat, Narendra and Shekhawat, R.S. 2015. Effect of In-situ moisture conservation practices on growth, yield and economics of pearl millet under dryland conditions. Journal of Soil \& Water Conservation, 14 (4): 306-309.

Subbaiah, B.V. and Asija, C.L. 1956. A rapid procedure estimation of available nitrogen in soil. Current Science, 25: 259-260.

Verma, Amar Kant and Yadav, P.N. 2017. Influence of linseed (Linum usitatissimum L.) based cropping systems and integrated nutrient management on productivity potential under rainfed condition. Progressive Research - An International Journal, 12 (Special-III): 2060-2064.

Verma, Amar Kant and Yadav, P.N. 2018. Productivity and water-use efficiency of linseed (Linum usitatissimum L.)-based cropping systems as influenced by integrated nutrient management under rainfed condition. Journal of Soil and Water Conservation, 17 (1): 53-57.

Verma, Amar Kant., Yadav, P.N. and Awasthi, U.D. 2017. Studies on Linseed (Linum usitatissimum L.) based Intercropping systems as influenced by integrated nutrient management on yield and economics under moisture scarce condition. International Journal of Current Microbiology and Applied Sciences, 6 (11): 2309-2314.

Walkley, A.J. and Black, I.A. 1934. Estimation of organic carbon by chromic acid titration method. Soil Science, 37: 29-38.

\section{How to cite this article:}

Amar Kant Verma, P.N. Yadav, U.D. Awasthi and Rahul Ranjan. 2018. Production Efficiency and Soil Studies of Linseed (Linum usitatissimum L.) Based Intercropping Systems as Influenced by Integrated Nutrient Management under Rainfed Condition. Int.J.Curr.Microbiol.App.Sci. 7(12): 553-558. doi: https://doi.org/10.20546/ijcmas.2018.712.069 